\title{
CLINICAL FIGURES OF UGLINESS UP AGAINST METAPSYCHOLOGY1
}

\section{JOEL BIRMAN \& CRISTINA CERNAT}

\section{Joel Birman}

Universidade Federal do Rio de Janeiro (UFRJ), professor titular do Instituto de Psicologia, Programa de Pós-Graduação em Teoria Psicanalítica, Rio de Janeiro/RJ, Brasil.

Universidade Sorbonne Paris Cité, Paris Diderot. Diretor de Estudos em Letras e Ciências Humanas, professor e pesquisador associado do Laboratório Psicanálise, Medicina e Sociedade, Escola Doutoral de Psicanálise, Paris, França.

\section{Cristina Cernat}

Universidade Sorbonne Paris Cité, Paris Diderot. Doutora pelo Laboratório Psicanálise, Medicina e Sociedade, Escola Doutoral de Psicanálise, Paris, França.

\begin{abstract}
In this article we discuss the metapsychological aspect of the psychoanalytic research on the clinical figures of ugliness. If the problem of ugliness is often associated with metaphysics or social norms, we wish to emphasise that the feeling of being ugly affects any psychic functioning. The discrimination encountered by the ugly in any social unrest, is unconsciously linked to anxiety representations, which disturb ego familiarity, by revealing the strangewithin us. The aesthetic ambivalence that every subject feels towards himself, accompanied by the tension between the ego ideal and the ideal ego, shows the metapsychological character of such a problem.
\end{abstract}

Keywords: ugliness; ego ideal; ideal ego.

Resumo: As figuras clínicas da feiura à prova da metapsicologia. Neste artigo abordamos o aspecto metapsicológico de uma pesquisa psicanalítica sobre as figuras clínicas da feiura. Se a problemática da feiura é com frequência associada à metafísica ou às normas sociais, desejamos enfatizar que o sentimento de ser feio afeta todo funcionamento psíquico. A discriminação que o feio suscita em todo mal-estar social está inconscientemente ligada a representações angustiantes, que perturbam a familiaridade egóica, ao revelar o estranho adormecido em nós. A ambivalência estética que todo sujeito sente em relação a si, acompanhada de uma tensão entre Eu Ideal e Ideal do eu, mostra o caráter metapsicológico de tal problemática.

Palavras-chave: feiura; Eu Ideal; Ideal do eu.

DOI - http://dx.doi.org/10.1590/1809-44142018001001

\footnotetext{
${ }^{1}$ The present article is a result of the thesis Stigmatizing figures of ugliness in contemporary clinic. The role of aesthetic judgement and social unrest in the construction of the imaginary and fantasmatic self by Cristina Cernat, prepared at Paris Cité Sorbonne-Paris 7 University, under the supervision of Professor Joël Birman.
} 
W e propose to address the metapsychological aspect of this research, in the fields of psychoanalysis and psychopathology, addressing two fundamental questions: why do we discriminate the ugly and why are there subjects that feel ugly? These two axis of research raised other important and essential questions regarding the comprehension of the metapsychological functioning, and, in particular, of how the imaginary and fantasmatic construction of the self is achieved.

\section{CONTEMPORARY AESTHETIC NORMS IN FACE OF SOCIAL UNREST}

It seemed of the utter importance to address such a theme in our psychoanalytical field, especially in the contemporary western social unrest, in which aesthetically preoccupations acquire a place of ever growing importance. Having to meet image demands of social medias, the contemporary subject finds himself facing aesthetic suffering, for the relation to the object seems to be characterized by fear. Thus, the subject gains recognition from another through likes of posted photos, which immediately introduce in the relation an aestheticized judgment coming from this other.

We noticed that, for several years now, a growing number of patients have been seeking us complaining that they feel left out of an aesthetic norm, imposed by the illusory promise of contemporary happiness. To be beautiful constitutes a paradigm of the social, medical and hygienist discourse that, nowadays, one has to respect, failing which the subject is considered responsible and at fault. As sociologist Jean-Claude Kauffmann notices, beauty represents nowadays "a social selection operator" and "a major instrument of inequality" (KAUFFMANN, 2013/2015, p. 64).

The body's aestheticization and medicalization are, then, a social production that defines norms to be followed in order to embellish one's body. Those who don't integrate themselves in this normativity identify themselves through exclusion, marginalization and stigmatization. "The numbers are striking. Indisputable and consistent. They concern, first of all, beauty" (idem). From an aesthetic and loving point of view, beauty is always particular, unexpected, different; it awaits to be precisely revealed by the gaze. From the point of view of society, it must be something else altogether: a norm, unsurprising, easy to identify. Thus, it must be simple and clear, reducible to certain criteria, since said beauty plays a central role in all mechanisms of social sorting, whether upwards or downwards" (ibid, p. 63). We notice the term: "unsurprising". It seems, then, that aesthetics should not scare, but be the regulator of the arousal and the affects it provokes in its subject. It shouldn't request the unexpected, the unacceptable, the different that inhabits us. Even if beauty must touch us unconsciously, it must not awake in us an uncontrollable arousal, a boundless and, thus, normless drive. The aesthetic norm limits the arousal it might generate. Likewise, Jean-Claude Kaufmann tells us of "a norm that is easily identifiable". Which means, a recognizable normativity for every subject in the social mirror game with which we can identify ourselves, with that which resembles us, rejecting/stigmatizing every alter ego. Hence, if we marginalize the ugly, it's because it unconsciously affects our own image of the body. Indeed, it incarnates the body whose degeneration, disharmony and castration of the forms, reveal in us a feeling of disturbing strangeness. According to historian Jean Héritier, "the monster, the deformed, makes us recall the fears that inhabits the body itself: the fear of loosing bodily integrity" (HERITER, 1991).

In that sense, sociologist Claudine Sagaert says that if nowadays, corporal appearance occupies an important place through rigorous, "constraining and alienating" work on the body, ugliness presents itself "as a fundamental category that gives meaning to existence". "In this, ugliness is not only a quality that, like any other, contributes to the subject's identity, it is the measure by which all others are inflated or deflated; it is the quality of qualities, a meta-quality of sorts. As an identity marker, ugliness plays, thus, an essential role in intersubjective relation so that it becomes impossible to be, should we make it an abstraction" (SAGAERT, 2012, p. 83-97).

Analyzing several figures of ugliness in contemporary unrest, we have noticed that the reason we marginalize the ugly is because it awakes in us the stranger we are to ourselves. It becomes a source of 
disturbing strangeness, for it marks a moment of the ego during which the subject doesn't recognize himself anymore (whether in the mirror or in the image of another). It becomes difficult for him to project himself in that he deems ugly, the strangeness of another.

Being a source of taboo, we notice the discriminatory effect met by the thematic (the problematization) itself of ugliness. It is politically incorrect do talk of ugliness, for it must be diverted, forgotten, glossed over. But as the subject insists in having an indifferent attitude, he ends up looking this troubling and anguishing sight with eyes full of hate or filled with pity. It is no accident that the word "ugliness" contains, in certain languages, the root "hate". For instance, in Romanian, the adjective or adverb urât resonates the verb a urî (loathe). Likewise, in german, häBlich designates that which is ugly, deformed, disfigured and contains the radical hab (der hab which means hate).

Consequently, despite the sociological character of such aesthetic problematic, we consider that it is of an ethical order to question such thematic in our field; as Freud said in 1921, in Group Psychology and the Analysis of the Ego: "In the individual's mental life someone else is invariably involved, as a model, as an object, as a helper, as an opponent; and so from the very first individual psychology, in this extended but entirely justifiable sense of the words, is at the same time social psychology as well" (FREUD, 1921/2001, p. 117-217).

If we have treated this aesthetic problematic at the crossroads of several disciplines - psychoanalysis, history, anthropology, sociology, contemporary medicine, linguistics and fashion -, it's because it seemed essential to take into account the whole palette of processes that construct the identity. For, since we're dealing with metapsychological functioning, it becomes capital to consider the singular complexity that characterizes every psychic subjectivity.

As we have already observed, since aesthetic norms represent, for many subjects, a type of psychic suffering of which they feel the need to talk about, an important question is to know how to take charge of this suffering. One the one hand, medicine's hygienist discourse is aimed at preserving its chair, on he other, fashion increasingly makes seasonably fashionable clothes. Between fashion advertising and hygienist responsibility, the question that arises is to know where does the need felt of embellishing and taking care of one's body come from. Where does this need of performative greatness of the body that goes to such sportive, muscular, dietetic, aesthetic extremes originate from? Couldn't we find here the willingness to go beyond our mortal condition?

Fundamentally, every metapsychological question somehow touches existentialism, due to the simple fact that the subject must free himself from his condition of being-toward-death, as said Heidegger, but also because he deals with the difficulty of $m^{\prime}$ être ${ }^{2}$ (LACAN, 1972-1973/1975, p. 73) (of existing) of a subject with social unrest. In that sense, Paul-Laurent Assoun says: "Concerning beauty, Freud precisely defines it as that which psychoanalysis has the least to say about! By this, he seems to be saying that the psychoanalysis of art can't and won't adequately deal with aesthetic creation itself. But if we come to really dwell on it, unconscious knowledge can't avoid this double experience and that, due to two things. Concerning misery, it points towards an experience of lack, marked by an existential urgency of sorts. The miserable subject, in the true sense of the term, experiences in himself a lack that confines him to distress, from whence comes the fact that this experience is relayed to a metaphysical plane [...]. But, in the unconscious, Lack is lack of the Other (or the the other): misery expresses a deprivation in the heart of the subject itself..." (ASSOUN, 1989/1966, p. 90-91). It's, then, a mistake to consider the aesthetic question as being outside the clinical field, since, frequently, patients bring to therapy this real, this existential misery, this impossible mastery of themselves, of their body, their image, their social or mortal condition.

2 The development, says Lacan, is confounded with the development of mastery. This is where is becomes necessary to have a little ear, just like music - I am m'être [that sounds like master and would mean being to myself], I progress through $m^{\prime}$ êtrise [that sounds like mastery], I am m'être of myself and of the universe. 
It has, thus, been essential in the present paper, to interrogate the construction of the body image, the construction of the human being's aesthetic judgment, closely linked with social norms, bodily development but also the fantasies and anguishes found at the base of a intrapsychic tension.

\section{PSYCHIC REPRESENTATIONS OF UGLINESS AND THE AESTHETIC MASTERY OF ANGUISHES.}

Consequently, even if this problematic of ugliness represents, at first sight, a question of social or anthropological order, considering the very fact that it interrogates the psychic functioning of every being, it becomes absolutely pertinent for it to be treated by psychoanalysis. We have then asked ourselves if aesthetic concern is a passing fad or if it is rooted in the metapsychological functioning of every being. As we have already observed, even if the question seems to be of a more social, metaphysical or existential order, if the subject brings the psychic the suffering of feeling outside the norms to the therapeutical setting, it's because he incessantly asks himself what he represents to the other.

If this demand of acknowledgment that the subject addresses another also implicates an aesthetic questioning, namely "am I beautiful or not?", it's because, since the beginning of life, the mother, through her maternal care, not only nourishes her child but also name him by carrying him psychically. According to Dolto (1984), this gives him a basic image that allows him to stand and welcome a certain continuity of feeling himself existing. This means that the child will construct himself as a subject divided by an ambivalence regarding the other and himself, not being, then, divided by a pathogenic ambivalence. Such ambivalence concerning oneself creates an intrapsychic tension between the permanent doubt of knowing who we are and if we are loved by an Other (the place of the signifier, the signifier being for Lacan that which a subject represents for another signifier).

Taking on the metapsychological character of such a problematic, we would like, first of all, to emphasize that, just as any other, aesthetic representations immerse the subject in psychic ambivalence. We observer this in the attitude adopted by the subject when, in front of ugliness, as as he wishes to look away, he still remains fascinated, captured and astonished by it. Even if Freud doesn't speak of ugliness or beauty as such, he still presents us, twice, important informations for the comprehension of the origins of an aesthetic judgment in psychic life. In Civilization and its Discontents (FREUD,1930a/2010), he leaves us a little note concerning the "unaesthetic" aspect the genital organs. Freud addresses this implied ugliness in relation to beauty. It is indeed rare that the genital parts are considered beautiful (ibid, p. 72). Beauty is designated as a type of pleasure, having an arousing effect. In The sexual life, Freud says that only an erect sex could be considered beautiful (FREUD, 1969/2009); this shows that all that bears the mark of castration, the mark of lack, is unconsciously perceived as a representation of ugliness. Hence, due to the integration of that which is prohibited and to social censorship, the child represses the beauty of genital organs.

We notice, thus, thanks to a freudian psychoanalytic interpretation, that the psychic representations of ugliness are linked to the figures of the disturbing strangeness, to the unconscious and anguishing perceptions of castration and lack. Umberto Eco in his book On Ugliness (ECO, 2007), gives us the example of the image of a face in which the mouth is missing its teeth and whose sight disturbs us even if we do not know its owner. He says that in the face of the incompleteness of this set, we authorize ourselves to think that the person is ugly. Interpreting psychoanalytically, we can say that what anguishes the being is the bodily transformation, for it is a sign of the return of the repressed. Ugliness is, thus, associated to the lack and to that which is castrated. The construction of that which is beautiful and aesthetic, tries to veil this troubling lack, ugliness' unsettling deformity. Nevertheless, the clinic and the analysis of fantasies forces us to admit that beauty also seeks to veil that which is dirty, abject, the anal and all that disturbs the familiarity of the ego. Ugliness is unconsciously associated not only with that which is castrated and with lack, but also that which is dirty and deformed. 
According to Freud, behind the feeling of disturbing strangeness, is always hidden the anxiety of the castration complex, "... the troubling in the experience of life is produced when repressed childhood complexes are brought back to life by an impression or when overcome primitive convictions are, once again, confirmed." (FREUD, 1919/1985, p. 209-263). Next, he asks himself what are the situations or the people that might awake in us such feeling of disturbing strangeness. He says that a disturbing effect is produced when the boundaries between fantasy and reality are erased. We feel, for instance, this feeling when we don't know if we are dealing with a living or dead being. These are indeed troubling situations that are simultaneously familiar and disturbing. In fine, that which is unheimlich is the return of the repressed, for, according to Freud, that which we have repressed appears to us as strange, when, behind this strangeness, is hidden a childhood complex formerly familiar. Thus, all that was once repressed, returns, that which was familiar and came back under the guise of strangeness, also appears to us as ugly. The revelation of the real produces a disturbing representation of which ugliness is part.

This is where lie the metapsychological aspect of the ugliness problematic, defined by the subjective signification it acquires during the structuring of unconscious processes of each and every one of us. The drive renouncement (that also includes an aesthetic aspect, not least because not all can be considered beautiful) that the subject has to make designates the universal aspect of social unrest in which he must inscribe his body and its image.

The aesthetic renouncement and the division brought about by the neurotic structuring in the subject, makes us, indeed, grasp that beauty isn't psychically (unconsciously) represented as a beautiful form, but as that which veils the horror. Thus, the ambivalent representation beautiful/ugly is supported, in the unconscious dynamic of the psychic apparatus, by the absence/presence of that which represents the castrated. This shows that self aesthetic judgment, self aesthetic esteem don't concern only a good or bad shape, but the subject's place in the symbolic system. "If it speaks in the Other, whether the subject hears it or not in his ear, that is where the subject, by a logic anteriority preceding all awakening of the signified, finds its signifying place. The discovery of that which it articulates there, that is to say, in the unconscious, allows us do grasp at the cost of what division (Spaltung), he is thus constituted" (LACAN, 1958-1966/1999, p. 163174).

In addition, for Lacan, aesthetic judgement allows to limit the destructive flow of jouissance and desire. If aesthetics constitutes a barrier that stops the subject in face of the destructiveness of radical desire, we can ask ourselves if ugliness isn't an unconscious construction aimed at mastering sexuality and the drive. If, in the beginning, genital sex was considered beautiful, moral ugliness limits the arousal it can create, whence that connection that we notice between ugliness and morals. Consequently, if ugliness serves to limit the damages of seducing beauty, we asks ourselves if beauty, a contrario, doesn't serve to master the anxiety that the sight of ugliness produces.

If, through a Freudian interpretation of the discovery of the anatomical difference of sexes or the anxiety of castration, we could see that aesthetics serve to mask lack, to question the anxiety of death and degeneration felt by every subject, has offered us the possibility to understand a fundamental aspect of a being's psychic functioning. We notice that the anxiety of death pushes the subject to embellish and maintain his body, as well as it pushes him to deny the disturbing strangeness that ugliness provokes. If we protect ourselves so much from this anguishing sight, it's because it is difficult for us to project ourselves in the image that the deformed presents us. We fear our body's degeneration, our image's degradation and, finally, we fear to someday become still, sick, without protection and very dependent of another.

In order to deal with this anxiety of death, the human being needs to be acknowledged by another, which gives, from an early age, the feeling of an existing continuity, fundamental, according to Winnicott, to the child's psychoaffective development. To seduce another is, first and foremost, a need of acknowledgment and a need of not being alone when facing the distress imposed by anxiety when facing death. 


\section{THE AESTHETIC AMBIVALENCE THAT THE SUBJECT FEEL REGARDING HIMSELF AND THE TENSION BETWEEN THE IDEAL EGO AND EGO IDEAL.}

The clinic of different clinical fields (handicap's, breast cancer's, youth's, aesthetic surgeries', grief's), showed us that the feeling of being ugly can be a passing moment towards the psychic appropriation of a bodily transformation. Something appears reminding the subject how strange he is to himself; a feeling of non-recognition of oneself arises and the subject feels ugly, shameful, not being up to his ideal self. A feeling of intrusion thus comes, upset and break the ego's defenses, for we know, ever since Freud, that the ego is a psychic body that negotiates the symptomatic formation, caught between the id's satisfaction and the superego's demands (FREUD, 1923b/2001, p. 243-305). The feeling of ugliness represents an intrusion in the ego. That ugliness that produces a feeling of disturbing strangeness, is translated in the unconscious level by the feeling of intrusion experienced by the ego when he perceives himself imaginarily lacking something.

Thus, sickness, bodily metamorphosis through the years, accidents, death and the feeling of not being in accord with aesthetic norms, put the constructed image of our body to the test of new self image reappropriation, experienced as intrusive and as breaking the familiarity of the ego. This is because the impossible mastery of one's body creates the disturbing strangeness within the psychic apparatus. It deforms the familiarity of the ego. The ambivalence that the subject feels regarding himself and self doubt irrupts abruptly in his psychic familiarity.

An effect of real then appears and the subject ceases to recognize himself in the mirror game he plays with the introjected gaze of the Other (an interior gaze he constantly directs towards himself and that permanently judges him). That is how we have noticed that the feeling of ugliness appears when the ideal ego doesn't feel up to the ego ideal; the gap between a real image and the idealized image of oneself is too wide for an agreement and negotiation between them with no downgrading of oneself to be possible.

The clinic of aesthetic and reconstruction surgeries that precisely intends to treat the bad image of oneself, gives the testimony of this gap between real image and the fantasmatic one that pushes the subject towards an infinite discontent, despite the success of a surgery and the the transformation he wished. On one hand, the unconscious image is hardly treatable via passage to the act, without a therapeutical work on oneself that would firstly serve as a support so that the surgical event is not experienced as a non integrated event in the patient's historic and psychic temporality. On the other, the postoperative real image can never satisfy superego's demands for it is never up to the aesthetic greatness fantasied and desired by the ego ideal. We can, thus, say that every aesthetic surgery is in some way a narcissistic pain reparation surgery.

We notice, thus, a aesthetic tension that characterizes the functioning itself of the subject and the image he has of himself. This tension is rooted in the metapsychological confrontation existing between the ideal ego and the ego ideal. If we are indeed tyrannized between the guilt of being beautiful or the shame of being ugly, that is because we are never up to ours superego's demands or ego's ideals, whence the questioning influencing our self esteem: are we the Other's object of desire, are we loved and acknowledged by him?

\section{THE FEELING OF BEING UGLY AND THE QUEST FOR AESTHETIC ACKNOWLEDGMENT UNDERTAKEN BY THE SUBJECT WITH THE GAZE OF ANOTHER}

The clinic shows us, furthermore, that the feeling of his own ugliness touches the subject in his feeling of existence and his lack-of-being and of-having, which pushes him to ontologically interrogate what he represents to an Other. Consequently, the object of our identity quest lies beyond the mirror, in this ideal point, chosen in the gaze of the Other from whence we see ourselves as an objet cause of desire. When, indeed, the subject sees himself as an object with no phallic brightness, begins the state of unconscious misery in which his ego perceives the existence of his image, whence a feeling of shame that appears, for the subject feels unveiled in his castration and lack. He feels unmasked in his imposture, which prevents him of letting 
himself be seen as such by another. He has trouble being assertive. Thus, he feels himself as repulsing or not beautiful enough to enter game of seduction with the gaze of another. We noticed, thus, that the subject flees the eye on another, fearing being disappointed of not being loved by him. This bond woven between the feeling of being ugly and the shame shows us, once more, the onto-metapsychological question that such aesthetic problematic stresses in our field.

Ugliness' social rejection appears, thus, as a double meaning sharp edged that unconsciously confines the subject in a vicious circle: on one hand, there are situations when the other's gaze is perceived by the subject as discriminatory, which provokes a narcissistic wound; on the other, clinic shows that there are also subjects that have a bad image of themselves and who unconsciously seek the other's rejection. In other words, the ugly perception of one's self concerns the discriminatory gaze of another as well as the interpretation that the subject will give to this other's, this alter ego's gaze. Nevertheless, we must not forget the superegoic eye that watches from within the subject and who plays a fundamental role in the constitution of self esteem (which also implies aesthetic self esteem). If we are talking about an introjected gaze of the Other, it's because this is how the child has seen himself being seen during the mirror stage. The Other's function is fundamental in recognizing oneself. Henceforth, here lies formulated the hypothesis according to which the feeling of ugliness is born out of the subjective production of another's gaze and of an introjected Other's gaze.

However, oneself' s sense of uglyness is inscribed in the symbolic chain. It is constituted from the first image that the child meets in the eyes of his mother, an image that is like a mirror (WINNICOTT, 1971/1975), or in the nomination of an Other (LACAN, 1949/1999, p. 93-124). As she takes care of her child, the maternal figure also carries him through the construction of a self or an $I$, for, according do Winnicott, when this sufficiently good support fails, the child looses his vitality and will has trouble to feel existing in a continuity, which will make him adopt a false self. He writes, converning this: "What does the baby see when he looks at the mother's face? Generally, what he sees is himself. In Other words, the mother looks at the baby and what he face expresses is in direct relation with what she sees" (WINNICOTT, 1971/1975). Consequently, to be seen procures a primordial feeling in his psycho-somato-social construction, that is, the feeling of feeling oneself exist.

So the mother does more than just take care of her child; in her eyes, the child feels himself existing, which gives him support and a identitary foundation in order to display a real self. To not feel loved lowers our self esteem, as it was already said by Freud in On narcissism, so, to feel as rejected or abandoned by his mother can provoke in a child, from a very early age, a lowering of his esteem (which also implies his aesthetica esteem).

The aesthetic quest is, thus, characterized by processes of resemblance and differentiation, marking the division of the self image between real self representation and idealized image to which one would like to correspond. The ideal ego can be, according to Jean-Claude Liaudet, the origin point of interior conflicts. "As far as the self is not found in the ego ideal, as far as I have the feeling that I'm not as I should be, I will depreciate myself. We have here, one of the sources of the lack of self reliance, due to an overly strong ego ideal. As we say, the bar is set very high" (LIAUDET, 2004, p. 3). If the subject integrated powerful ideals, deeply rooted in the self as fundamental aesthetic model in order to please to feel as existing in the gaze of the Other, he will be more inclined to devaluate himself aesthetically. Likewise, he will be lead to display a lack of self confidence in his aesthetic capacities.

Besides, in this time and age in which the aestheticization of our image acquires a more important place in the relation the subject entertains with another, we can suppose that low self esteem can house itself in a symptomatology with an aesthetic aestheticized connotation.

Moreover, the clinic daily shows us that the child constructs himself from processes of identification and differentiation from others, which implies the fact that, comparing himself with them, he might feel inferior 
for he doesn't correspond to the demands he supposes the others makes him. In addition, how the group sees puberty also influences the aesthetic choices of some of us, even if the group's choice is based on a family model. That is why the way a subject aesthetically sees himself must be analyzed through a multitude of psychological, social and bodily processes whose wavering is to be found at the base of any self imaginary and fantasmatic structure.

To talk about this vast palette of processes doesn't mean that the problematic of ugliness is not of an metapsychological order. We notice, on the contrary, the opposite, since, for starters, the subject is a social being, for he needs another to construct himself. And how he'll see how he's seen by this other will be essential to construction of the (aesthetic) image of his body.

\section{THE FANTASMATIC ANATOMY IN FRONT OF THE ANXIETY OF BEING DEFORMED - PARADIGM OF EVERY INTRAPSYCHIC CONSTRUCTION.}

We have, thus, addressed the matter from the point of view of a selffantasmatic anatomy, since fantasies play a determining role in the subjective construction of an esthetic perception of the self. We have analyzed many fantasies that seem essential in the formation of the aesthetic judgement (this aesthetic perspective through which the subject sees himself as well as another). Contagion, immortality and seduction fantasies that are closely linked to the anxieties of castration, degeneration and death. They lead the subject to autoconservation, to preserve his flesh, to embellish his body and to want to be the object that causes another's desire. We have noticed that dysmorphophobia (the fear of being deformed) have strong connection to the anxieties of castration, degeneration and death. The fear of becoming ugly or deformed is derived from this unconscious impossibility, as stated Freud, one has of representing oneself's own death. Furthermore, it's these anxieties that lead us to reject and stigmatize ugliness. It's our own anguish in front of the unknown that is death, or rather, in front of that which comes after death, that lead us to preserve ourselves embellishing us, following hygienic orientations, taking care of our body etc. The anxiety of death plays a determining role in the construction of the imaginary and fantasmatic self. We present with this yet another metapsychological aspect of the present psychoanalytical study of aesthetics: every psychic process is built from the anxiety of death, as well as it revolves around the psychic tension between life drive and death drive.

Nevertheless, a last question remains to be evoked, that which concerns the ethical place of the psychologist in matters concerning the risks presented by the erasure of the feeling of ugliness or of the dysmorphophobic syndrome that cognitive behavioral oriented therapists propose to their patients. If the feeling of being ugly represents the only way for a being to feel himself existing for another, to suddenly eradicate this symptom can constitute a psychic violence, the risk being to periclitate a defense mechanism and to cause a psychic collapse. What might the subject put in place in order to express his aesthetic suffering, his existential unrest or his psychic misery? To feel ugly is an affect that, in the psychic apparatus, always comes with a whole palette of processes (psychic, social, ontological, etc.) as well as others affects and feelings, whence the importance to considerate the subject not only in his symptomatology, but also in his singular psychic complexity.

\section{THE AESTHETIC DISSATISFACTION AS AN ONTOLOGICAL CONDITION OF BEING}

A great metapsychological lesson that can be drawn out of this research is that the aesthetic dissatisfaction is an ontological condition of the being. Because of the psychic conflictual aspect opposing death and life drives, between the guilt of being beautiful and the shame of being ugly, between oneself and another, the familiar and the strange, between id and superego, the human being is led to judge himself aesthetically and not always to feel up to superegoic demands, to the demands of his ego ideal. We all have moments when we feel estranged from ourselves, moments when we doubt ourselves for not being able to cause desire in another. 
"Actually", says Nasio, "our self is a group of changeable and frequently contradictory images" (NASIO, 2013, p. 81). Our psychic apparatus must permanently assimilate the changes that the body endures and the question that poses itself of how to deal with it, if he prefers repetition over unpredictability, if he prefers meaning over chaotic chance. How does the real of the body, the somatic illness work our body image. How to place oneself when in front of castration and of our mortal condition?

To feel loved represents an existential need common to every being, for it offers a meaning to our existence an to our feeling of being-towards-the-world. Furthermore, according to Jean Oury (2008), the dive into aesthetic mastery cannot be reduced to the anal mechanism, as it is frequently described by psychoanalysis. The aesthetic quest is, fundamentally, an existential project, a life's "aesthetic connotation motor", addressed to another, to the Other and that seek to establish a set of psychic processes resulting in a aesthetic act (OURY, 2008).

However, being always divided by his neurotic structuring, every subject can, at one point, doubt himself and the love another bears him. Who has never experienced in his life this mirror event, in which we don't recognize that which we see? Who has never had this strange sensation of not being like the others, of feeling inferior to norms inflicted by social aesthetic demands? Isn't it about a mirror that Freud tells us of strange and disturbing personal experience? Ugliness representations give the testimony of this ambivalent tension that every subject feels towards himself. Such ambivalent tension between being familiar or strange to oneself has its roots in the fact that the being is constituted from resemblance and differentiation processes. Thus, there is always another/an Other lying at the base of identity, imaginary and fantasmatic construction.

The representations of ugliness give the testimony of this disturbing stranger that we are to ourselves and of the fact we ignore what lies in the foundation of our ego in mirror stage, as Lacan previously pointed. In the end, what do we seek in a mirror, if not the reassurance of the existence of our identity, it's justification, it's significance to an Other, in which eyes we suppose ourselves to be the cause of its desire? "He who sees himself in a mirror takes a risk, for a mirror is also an instrument of knowledge just as it is an instrument of ignorance or even an instrument of disturbing strangeness. Wasn't it about a mirror that Freud tells us of a personal experience of Unheimlich?", notices Simone Korff-Sausse (2001/2010, p. 20).

In 1921, in Group psychology and analysis of the Ego, Freud notices: "There is always a feeling of triumph when something in the ego coincides with the ego ideal. And the sense of guilt [PEP] 1 [PEP] 11232 of 39 (as well as the sense of inferiority) can also be understood as an expression of tension between the ego and the ego ideal" (FREUD, 1921c/2001, p. 117-217). In 1933, Freud mentions the fact that psychoanalysis makes barely use of the complex of inferiority. However, we must not separate it from the guilt complex, for this feeling must be understood by the tension existing between the ego and superegoic demands, says the psychoanalyst, specially since its deep roots are erotic (FREUD, 1989, p. 91-92). Finally, we can say that, in each and every one of us, there is a tension between ego and superego, between ideal ego and ego ideal. And, often, it is due to this inner conflict that the subject may feel as being not up to the ego ideal.

\section{CONCLUSION}

As we could see, the human being is never entirely satisfied with his image; he finds himself divided between a real image and an idealized/fantasized one, between an ideal ego and an ego ideal. This indeed constitutes a great metapsychological lesson to be drawn from a problematization of psychic representations of ugliness in our analytic field.

If our body represents at the same time something familiar and strange, it's because our image is never integrally acquired as such. We never know who we are. On one hand, since we can't see our body as a whole, we can't know what image we send to others. Likewise, as we see ourselves in the mirror, we often only notice our face. "By definition, the appearance is that which is immediately perceivable to the sight: we recognize here the scopic image. The appearance is also that which we perceive in opposition to the reality of the self, 
that which eludes us: we, once again, recognize the scopic image but through a primordial distinction with the reality of which it offers only a vision, an interpretation and a translation. The forced passage trough 'the tool, or, better, the organized mediator between the subject and the world', doesn't give a sensorial decoding, a vision of the body, and the body scheme stays 'an abstraction of the experience of the body in the three dimensions of reality'. This turns the image not into the reality but into a reality" (LOLLINI, 1990, p. 14). Indeed, we don't see ourselves, we perceive ourselves in the mirror, we imagine ourselves through the eyes of another. A patient who resorted to aesthetic surgery, told, during a session, of the effect of disturbing strangeness that she felt when looking in the mirror one morning and suddenly seeing the bodily changes that happened to her buttocks, when, before that, se only took notice of her face.

Likewise, for the psychoanalyst Gérard Bonnet, our inner image can't be reduced to one simple image, for it is constructed through time from "a certain number of retained and favored elements as we progressively move through existence". "The shape of the eyes, the fold of the lips, a way of putting forward the chin, a color of hair, but also the specific intonation of our voice, our smell, our touch, our taste, our ambition: our image is a living icon, made from several unique traits".

Furthermore, for him, the image we have of ourselves will be beautiful if it matches the idea we have of ourselves (BONNET, 2013, p.167). Indeed, an ideal to which we would like our image to correspond, is not represented by something incomparable or wonderful, nor by something that must be dictated by fashionable canons; it's, first and foremost, an ideal interiorly conceived, often constructed by criteria specific to each and every one. This shows that the self image is always a fantasized and idealized interpretation that deform the real self image. It is the result of a subjective affect that we have towards ourselves.

We can, thus, emphasize that the aesthetic worry of oneself is more than a contemporary, social, metaphysical or philosophical question; it is, first and foremost, a metapsychological question that concerns each and every one's fantasmatic and imaginary construction, as well as his psychic structuring. And if it is the social that defines aesthetic norms, we can still ask ourselves what constitutes social norms. Isn't there an answer to the anxieties of the being, a mastery of that which concerns the drive, a solution that we found to deal with the strange familiarity that inhabits us? If we admit the hypothesis according to which beauty is a construct seeking to master the anxieties that ugliness awake in us, as well as ugliness is a construct that seeks to limit the damages that the seduction of beauty can cause, we can say that that the social itself is a collective creation used by human beings to supplement a paternal protecting function. The role of the social apparatus is, thus, to master the human being's overflowing anxieties and drives.

Social processes are, thus, woven into psychic and bodily ones, intrinsically connected. To address such a problematic of ugliness without taking into account the complexity of this weaving would mean to overlook the subjective and historic singularity in which the feeling of ugliness is inscribed. The metapsychological character of such a problematic forces such a transdisciplinary approach, for, in order to treat a subject's aesthetic suffering and existential unrest, it is necessary to not overlook the social unrest in which he is inscribed and inscribes it.

Received: December 12, 2015. Accepted: June 10, 2016.

\section{REFERÊNCIAS}

ASSOUN, P. L. Le pervers et la femme (1989). Paris: Anthropos/ Economica (2 ${ }^{\text {ème }}$ édition), 1996.

BONNET, G. La tyrannie du paraître. Faut-il se montrer pour exister? Paris: EYROLLES, collection Comprendre \& Agir, 2013.

DOLTO, F. L'image inconsciente du corps. Paris: éditions du Seuil, 1984.

ECO, U. (dir.), Histoire de la laideur. Trad. de l'italien par Myriem Bouzaher, trad. du latin et du grec par François Rosso. Paris: Flammarion, 2007.

Ágora (Rio de Janeiro) v. XXI n. 1 jan/abr $2018 \quad 1-11 \quad 10$ 
FREUD, S. La vie sexuelle (1969). Paris: PUF, 2009. . Le moi et le ça (1923b). Trad. Jean Laplanche. In: Essais de psychanalyse, Paris: Petite Bibliothèque Payot, 2001.

L'inquiétante étrangeté (1919h). Trad. B. FERON. In: L'inquiétante étrangeté et autres essais. Paris: Gallimard, 1985. . Malaise dans la civilisation (1930a), trad. d'allemand par Aline WEIL, Paris: Petite Bibliothèque Payot, 2010.

. Nouvelles conférences d'introduction à la psychanalyse. Trad. R. M. Zeitlin. Paris: Gallimard, 1989

. Pour introduire le narcissisme (1914c). Trad. Jean Laplanche. In La vie sexuelle. 2009.

. Psychologie des foules et analyse du moi (1921c). Trad. Pierre Cotet; et al. In: . Essais de psychanalyse. Paris: Petite Bibliothèque Payot, 2001.

HERITIER, J. Le martyre des affreux. La dictature de la beauté. Paris: Denoël, 1991.

KAUFFMANN, J. Aimer son corps. La tyrannie de la minceur. Paris: Pocket, 2013.

KORFF-SAUSSE, S. Figures du handicap. Mythes, arts, littérature (2001). (Première édition en 2001 sur le titre $D^{\prime} \mathcal{C}$ dipe à Frankenstein. Figures du handicap) Paris: Payot \& Rivages, 2010 .

LACAN, J. Encore (1972-1973). Paris: Seuil, 1975. (Séminaire, 20). 1999.

. La signification du phallus (1958-1966). In Ecrits II. Paris: éd. Du Seuil,

Le stade du miroir comme formateur de la fonction du Je telle qu'elle nous est révélée dans l'expérience psychanalytique (1949). (Communication faite au XVlème congrès international de psychanalyse, à Zürich. In: Écrits (tome I). Paris: Seuil, 1999.

LIAUDET, J. Croire en soi ou la confiance perdue et retrouvée. Paris: éditions l'Archipel, 2004.

LOLLINI, M. F. L'irréparable outrage. La psychothérapie analytique face à la chirurgie esthétique. Paris: éditions Universitaires, 1990.

NASIO, J. A. Mon corps et ses images. Le corps est la voie royale qui mène à l'inconscient! (2007). Paris: éd. Payot \& Rivages (première édition poche), 2013.

OURY, J. Essai sur la création esthétique. L'imaginaire esthétique comme facteur d'intégration biopsychologique. Paris: Hermann, 2008.

SAGAERT, C. Beauté et laideur dans le portrait de Dorian Gray (2012). Forma. Revista $\begin{array}{lllll}\text { d'Humanitats, } & \text { v. } & 6 . & \text { Disponível em: }\end{array}$ <http://www.raco.cat/index.php/Forma/article/viewFile/261159/348364>.

WINNICOTT, D. Le rôle de miroir de la mère et de la famille dans le développement de I'enfant (1971). In: Jeu et réalité, Folio essais. Paris: Gallimard, 1975.

\section{Joel Birman}

joelbirman@uol.com.br

\section{Cristina Cernat}

cristina.cernat@hotmail.com

\section{Lourenço Astúa de Moraes}

l.astua@gmail.com

Traduzido do francês por Lourenço Astúa de Moraes / Translated from French by Lourenço Astúa de Moraes. Pontifícia Universidade Católica do Rio de Janeiro (PUC-Rio), mestre pelo Programa de PósGraduação em Psicologia Clínica, Rio de Janeiro/RJ, Brasil. 